\title{
MEASUREMENT OF PHYTOPLANKTON POPULATION BY THE PIGMENT EXTRACTION METHOD
}

\author{
By A. C. Gardiner \\ The Laboratories, Metropolitan Water Board, London
}

Harvey's method of estimating concentration of planktonic algae was used by him to study seasonal abundance of net-caught algae in the waters around Plymouth (Harvey, I934). His data showed that, in these circumstances, good agreement was to be expected between depth of tint of an acetone extract of algal pigments and the amount of algae, reckoned in terms of number multiplied by area or volume of individual cells (Harvey, I935, p. I82). It does not necessarily follow, however, that agreement will be equally good in different circumstances. It is known, for instance, firstly, that the 'Harvey Standard' has not the same colour composition as acetone extracts from freshwater phytoplankton and, secondly, that extracts from phytoplankton collected at different seasons or from different localities are not of uniform colour (Riley, I938, p. 37I ; Kozminski, I938, p. I44). The colour of an acetone extract varies with the qualitative composition of the plankton; hence in the sea, as in fresh water, it is not to be expected that extracts from collections in which Bacillariophyceae (diatoms), Chrysophyceae (e.g. Phaeocystis, see Savage \& Hardy, I934) or Dinophyceae predominate will be of the same colour. It is the object of this paper, firstly, to specify two essential conditions which must be satisfied before the pigment-extraction method can estimate without avoidable error the concentrations of marine or freshwater phytoplankton and, secondly, both to indicate certain problems in need of further investigation and to suggest some lines of approach to these problems.

\section{The Pigments in Planktonic Algae}

Recent work by Kylin (I927), Seybold \& Egle (I938), Carter, Heilbron \& Lythgoe (I939) and Heilbron (I942) on the pigments present in the various classes of algae must be the starting point for a critical examination of the reliability of any modification of the Harvey method. The following composite table, abridged from the works referred to above, summarizes the chief differences between some classes of algae, members of which are likely to form the major part of a marine or freshwater plankton.

Seybold \& Egle (I938) are of the opinion that chlorophyll B is completely absent from all classes of algae examined by them, save the Chlorophyceae. This view is not shared either by Kylin (I927) or by Dutton \& Manning (I94I, p. 52I), and the latter authors prefer to write about the 'near absence' rather than the absence of chlorophyll B in the diatom Nitzschia closterium. 


\begin{tabular}{|c|c|c|c|c|c|c|c|c|}
\hline & 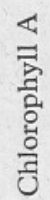 & 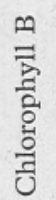 & 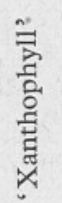 & 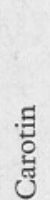 & 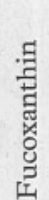 & 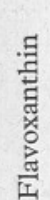 & 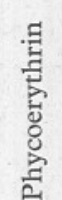 & 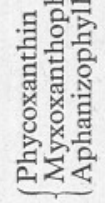 \\
\hline CHLOROPHYCEAE & + & + & + & + & - & - & - & - \\
\hline BACILLARIOPHYCEAE & + & - , & + & + & + & - & & \\
\hline CHRYSOPHYCEAE & + & - ? & + & + & + & - & - & \\
\hline MYXOPHYCEAE & + & & + & + & - & + & + & \\
\hline DINOPHYCEAE & + & - & $+?$ & + & & & & \\
\hline
\end{tabular}

All workers are agreed, however, that in algae other than the Chlorophyceae the amount of chlorophyll B is very small indeed.

The pigments common to the classes of algae in the above table are chlorophyll A, 'xanthophyll' and carotin, and further work may show that these three are common to all aquatic algae. The first essential condition, then, is that the estimate of algal abuntanse must be based on the concentration of one (or more) of these common pigments.

\section{The Solubility of Algal Pigments in Acetone}

If a mixed sample of freshwater algae be extracted for $\mathrm{I} 2-24 \mathrm{hr}$. either with pure or $80 \%$ acetone in the cold, it is immediately apparent from examination under the microscope that only certain species have been completely decolorized. Virtually all diatoms will appear colourless; very many species of Chlorophyceae will apparently have lost but little of their original colour; certain of the Myxophyceae, including Aphanizomenon, Anabaena and Microcystis will be pale or dark blue; Tribonema (Xanthophyceae) and Ceratium (Dinophyceae) will be far from completely decolorized. Methyl alcohol is somewhat superior to acetone in its solvent action upon Chlorophyceae and Myxophyceae; it is inferior to acetone for diatoms. A mixture of equal parts of methyl alcohol and benzene has proved a good solvent. Pigments should be extracted as soon as possible after collection, for there is a loss of certain pigments when algae are dried in air (Seybold \& Egle, I938, p. 56). The second essential condition, then, is that the solvent must extract completely the chlorophyll $A$, 'xanthophyll' or carotin from all members of a phytoplankton.

\section{The Constancy of the Amounts of the Common Pigments IN THE AlgAL CELL}

In higher plants it is known, firstly, that "the amount of chlorophyll A and B is not far from being constant, namely 0.6 to $\mathrm{I} \cdot 4 \mathrm{grm}$. per IOO grm. of dried leaves', secondly, that 'the total weight of carotin and xanthophyll is from 0.07 to $0.2 \mathrm{grm}$. per $100 \mathrm{grm}$. of dried leaves, the ratio of carotin to xanthophyll being about $0.6^{\prime}$ (Baly, I940, p. I4). Excluding plants living in deep shade, it is probably not far from the truth to assert that the leaves of all terrestrial plants in this country receive light of the same spectral composition. In waters 
of widely differing colour and turbidity it is quite certain that the spectral composition of the subsurface light will not be constant (James \& Birge, 1938, pp. 56-7; Cooper \& Milne, I938, p. 526). Stanbury (193I, p. 650) has shown that the colour of the diatom Nitzschia closterium varies from 'a rich dark brown shade to a decided greenish tint', when grown under light of different wave-length. Since the pigments normally present in diatoms are chlorophyll A, 'xanthophyll', carotin and fucoxanthin, it is, perhaps, legitimate to conclude by analogy from higher plants (Egle, 1937, p. 573) that any induced colour change will be the result of a shift in the ratios of the pigments. It follows, then, that in waters of widely differing colour and turbidity estimates of algal abundance based upon the extraction of one or more common pigments might be subject to considerable errors.

It has been suggested that the chlorophyll content not only varies with the physiological state of the algal cell, but also is not constant in different classes of algae (Riley, I940, pp. 286-7). Chlorophyll separated by saponification with $\mathrm{KOH}$, the method used by Riley, will be a mixture of chlorophylls A and $\mathrm{B}$ at those times when Chlorophyceae predominate; when other classes of algae are dominant it will be chlorophyll A only. The difference in the solvent action of acetone towards the several classes of algae must also be taken into account before the amounts actually present can be compared.

The reliability of the pigment-extraction method will depend to a great extent upon the constancy of the ratios of the common pigments both at different seasons and in different classes of algae, and it is imperative that measurements designed to put these points to the test shall be made. The selection of the common pigment should be influenced not only by the relative amount present in the different classes of algae, but also by the ease of separation (vide infra).

\section{The Separation of Plant Pigments}

Complete separation of algal pigments is possible by the Tswett chromatographic technique (Carter, Heilbron \& Lythgoe, I939; Cook, I94I; Zechmeister \& Cholnoky, I94I). Of the various algal pigments, chlorophyll A is present in the greatest concentration, whence it follows that extracts from smaller quantities of algae would give more easily readable colours than would be the case if another pigment were selected as the common pigment. Owing to the ease with which carotin can be separated, however, the selection of carotin has much to recommend it. One of the real advantages of the Harvey method is the speed with which determinations can be made, and it is very desirable to retain this feature if possible. Methods for the separation of carotin in silage are modifications of the Tswett technique and details will be found in a recent paper by Bolton \& Common (1942, p. 5I). Should, however, chlorophyll A be selected, the standard for comparison must either be an artificial one or a solution of chlorophyll A, as used by Krey (1939, p. 205). Commercial chlorophyll being almost certainly prepared from higher plants 
(and hence a mixture of chlorophylls A and B) cannot be used as a standard except for Chlorophyceae.

\section{General Considerations}

There is insufficient evidence at the moment upon which to base an opinion as to the magnitude of the error likely to arise from seasonal or specific variations in the content of a common algal pigment. Gillam, El Ridi \& Wimpenny (1939, p. 86), it is true, have stated that 'it seems unlikely that any arbitrary colorimetric measurement based on the amount of chlorophyll present in an acetone or ether suspension will give more than a rough estimate of the diatoms present in any sample', but it seems essential to obtain further data. If it may be assumed for the moment that the concentration of a common pigment is relatively constant in all classes of algae, there is little doubt that estimates based upon the complete extraction of one or more common pigments will tend to approach nearer the truth than will estimates expressed in terms of numbers multiplied by area or volume of individual cells. The difficulties of making such weighted counts are considerable; at seasons when Myxophyceae are dominant in a plankton they are very great. If it should turn out that wide differences are characteristic of the several classes of algae, it may be necessary to know the relative proportions of the different classes present. The chlorophyll B, fucoxanthin, 'phycocyanin' ratio would provide an approximate estimate of the proportions of Chlorophyceae, Bacillariophyceae plus Chrysophyceae and of Myxophyceae.

Although, admittedly, there are times, particularly in the spring, when agreement between weighted counts and depth of tint of an acetone extract is good, it is very unlikely that any modification of the Harvey method proposed to date, including that in use in these Laboratories, is sufficiently free from avoidable error to be more than an approximation. Hence, regional surveys in which chlorophyll is used as a measure of phytoplankton production (Deevey, I940) may well give a misleading impression. It is essential not only to recognize the limitations of the method, as Riley has done (I939), but also to appreciate the factors, which in all probability, are responsible for a large part of these limitations. There is little doubt that certain sources of error can be eliminated and no time should be lost in seeking an improved technique. Unless this be done there is danger that much field work will later be found to have been of doubtful value.

My thanks are due to Lt.-Col. E. F. W. Mackenzie, O.B.E., M.C., Director of Water Examination, Metropolitan Water Board, for permission to submit this article for publication.

\section{SUMMARY}

I. In order that the Harvey method shall estimate without avoidable error the concentration of marine or freshwater phytoplankton, it is essential, firstly, 
that the estimate be based upon the concentration of one or more pigments common to all classes of algae, secondly, that the solvent selected shall extract completely the common pigments.

2. Attention is directed to the possible influence of the spectral composition of subsurface light upon the pigment ratios in algal cells.

3. The use of carotin as the common pigment is suggested owing to the ease with which this pigment can be separated.

4. Failure to recognize the limitations of the method may materially reduce the value of certain types of field work.

\section{REFERENCES}

Baly, E. C. C., I940. Photosynthesis. London.

Bolton, W. \& Common, R. H., I942. Modifications of Moon's method for the estimation of Carotene in silage. Fourn. Soc. Chem. Ind., Vol. LXI, p. 50.

Carter, P. W., Heilbron, I. M. \& Lythgoe, B., I939. The Lipochromes and Sterols of the algal Classes. Proc. Roy. Soc. B, Vol. Cxxvin, p. 82.

Cook, A. H., I94I. Chromatographic Analysis. Institute of Chemistry, London.

COOPER, L. H. N. \& MILNe, A., I938. The ecology of the Tamar Estuary. II. Underwater illumination. Fourn. Mar. Biol. Assoc., Vol. xxir, p. 509.

Deevey, E. S. Jr., 1940. Limnological studies in Connecticut. V. A contribution to regional limnology. Amer. Fourn. Sci., Vol. ccxxxviII, p. 7 I 7.

DutTon, H. J. \& MANNING, W. M., I94I. Evidence for carotenoid-sensitized photosynthesis in the diatom Nitzschia closterium. Amer. Fourn. Bot., Vol. xxvirI, p. 5 I6.

Egle, K., I937. Zur Kenntnis des Lichtfeldes der Pflanze und der Blattfarbstoffe. Planta, Bd. xxvi, p. 546.

Gillam, A. E., El RIDI, M. S. \& Wimpenny, R. S., I939. The seasonal variation in biological composition of certain plankton samples from the North Sea in relation to their content of Vitamin A, Carotenoids, Chlorophyll and total fatty matter. Fourn. Exper. Biol., Vol. xvi, p. 7 I.

Harvey, H. W., I934. Measurement of phytoplankton population. Fourn. Mar. Biol. Assoc., Vol. xIx, p. $76 \mathrm{r}$.

- I935. Note concerning a measuring plankton-net. Fourn. d. Cons. Internat., Vol. x, p. I79.

Heilbron, I. M., I942. Some aspects of algal chemistry. Fourn. Chem. Soc., Feb. I942, p. 79.

JAMES, H. R. \& BIRGE, E. A., I938. A laboratory study of the absorption of light by lake waters. Trans. Wis. Acad. Sci., Vol. xxxI, pp. I-I54.

Kozminski, Z., I938. Ueber die Chlorophyllverteilung in einigen Seen von NordostWisconsin (U.S.A.). Arch. d'Hydrobiol. et d'Ichthyol. T. XI, p. I2O.

KREY, J., I939. Die Bestimmung des Chlorophylls in Meerwasser-Schöpfproben. fourn. d. Cons. Internat., Vol. xIv, p. 201.

KyLIN, H., I927. Ueber die karotenoiden Farbstoffe der Algen. Hoppe-Seyler's Zeitschr.f. Physiolog. Chem., Bd. CLxvi, p. 38.

Riley, G. A., I938. The measurement of phytoplankton. Int. Rev. d. ges. Hydrobiol. u. Hydrog., Bd. xxxvi, p. 371 .

- 1939. Correlations in aquatic ecology. Fourn. Mar. Res., Vol. II, p. 56.

I940. Limnological studies in Connecticut. III. The Plankton of Linsley Pond. Ecol. Monog., Vol. x, p. 279. 
SAVAge, R. E. \& Hardy, A. C., 1934. Phytoplankton and the Herring. Fish. Invest., England, Ser. 2, Vol. XIV, pp. I-73.

Seybold, A. \& EgLE, K., I938. Quantitative Untersuchungen über Chlorophyll und Carotenoide der Meeresalgen. Fahrb. $f$. Wiss. Botanik, Bd. Lxxxvi, p. 50.

StANBURY, F. A., I93I. The effect of light of different intensities, reduced selectively and non-selectively, upon rate of growth of Nitzschia closterium. Fourn. Mar. Biol. Assoc., Vol. xvII, p. 633.

Zechmeister, L. \& ChOlNoky, L., I94I. Principles and Practice of Chromatography. London. 